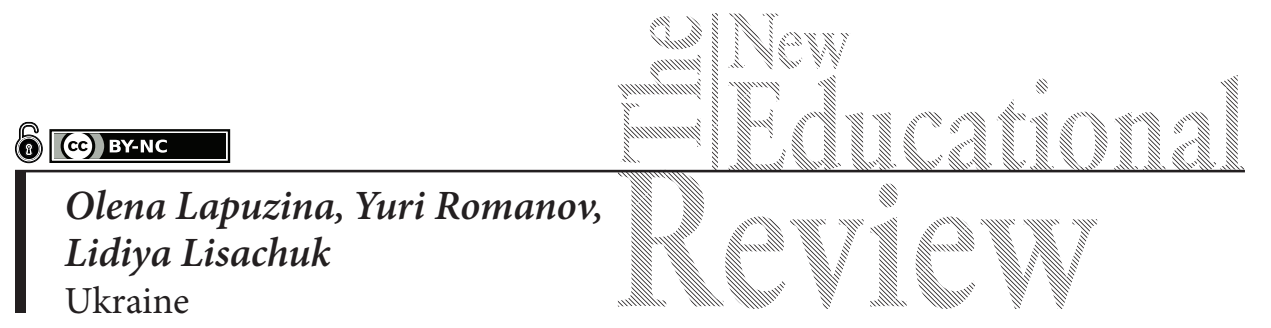

\title{
Professional Ethics as an Important Part of Engineer Training in Technical Higher Education Institutions
}

DOI: 10.15804/tner.2018.54.4.09

\begin{abstract}
This article underscores the importance of professional ethics studies for future engineers in a modern education system. The purpose of the research was to show how university teachers could help future engineers acquire their skills in techno ethics, ecological ethics, computer ethics skills, etc., by teaching an interactive course "Professional Ethics for Engineers". The research was conducted using data obtained from 418 university students and 88 engineers. The results of the completion of the course made it possible to conclude that the case study method would become an effective tool to form future engineers' professional needs, interests, opinions, life values, and positive world outlook.
\end{abstract}

Keywords: professional ethics, techno ethics, ecological ethics, computer ethics, modern engineer training, higher technical education

\section{Introduction}

Many scientists confirm that the development of modern science, information technologies, globalization, and business consequences of industrial activity may adversely affect the environment and human life. Entrepreneurs' activity, which has the only purpose of making a profit, despite the means to achieve it (corruption, theft of intellectual property, pollution of environment, etc.), may also have a negative influence (Mouton, Malan, Kimppa, Venter, 2015; DeMarco, 2017). 
In modern global economics, a positive outcome depends on the initiative, competences, and level of professional training. When there is a freedom of actions, it is important to learn how one can use this freedom ethically, correctly and comply with the accepted norms of business relations (Saat, Bakar, Rafai, Amin, 2012).

Due to the wide spread information technologies, global environmental problems aggravate, and global professional engineers' activity is being increased significantly (Karim, Zamzuri, Nor, 2009). Poor results of innovation provision and the lack of regulations create conflicts in social relations (Bond, 2009). Along with the growth of technical strength and the use of innovative technologies, there is a crisis in environmental, social, and cultural spheres, due to the disastrous lag in the development of an ethical society.

The relationship between economic success and observance of norms of professional ethics can be formulated as follows: Economics has moral premise and professional ethics has economic consequences. Otherwise, there are also economic conditions of professional ethics and moral consequences of economics. Professional ethics is a practical value, not a theoretical one. Professional ethics is aimed at resolving practical issues, not at moral grounds, versatile and based on existing and generally recognized moral values (Wang, Zhang, Zhu, 2015).

According to this, it was necessary to develop an overall context, in which activities in the market could be evaluated from the ethical point of view. Thus, many well-known enterprises and companies accepted new ideas, developed codes of professional conduct, organized centers of professional ethics, business ethics societies, and committees of businessmen and engineers.

Problems of professionals who possess the norms of professional ethics is a subject of the pedagogical research of many international scholars (Krishna, Dangayach, Jain, 2012; Kerta, Uz, Gecu, 2012; Pereira, Brisson, Prada, Paiva, Bellotti, Kravcik, Klamma, 2012; Farahani, Farahani, 2014; Behroozi, Qasemi, Fadaiyan, 2014; Gülcan, 2015; Miloradova, Ishkov, 2015, etc.). Professional ethics is already part of the curricula of many universities and business schools all over the world (Verrax, 2017).

The practice of market economy requires special training of new generation professional engineers, who will be not only high-level professionals, but also moral, decent, strong-willed and highly cultured members of society. The high level of creativity and the ability to advertise partners and potential customers ethically, convince them of the competitiveness of their products are also very important. Nowadays, engineer training with a focus on professional activities in a relatively narrow field does not correspond to the modern social demands or needs of the labor market. Adding the current educational paradigm with ethical components has become an urgent need of society (Holtzhausen, 2015). 
The ability to resolve this problem successfully creates, in turn, the need for theoretical and experimental research-pedagogical conditions and their effective pedagogical techniques instilling professional ethics in future professionals.

It is essential that the moral and ethical paradigm will be an integral part of engineers' education for serving society and ensuring its prosperity because the results of engineering activity penetrate the economic, scientific, social, and humanitarian spheres. An engineer is obliged to care about the comfort, safety, and environmental friendliness of the products that he/she produces. Nowadays, engineering activity requires solving social problems, such as liability, intellectual honesty, and professional ethics.

In pedagogical theory, the research of such well-known scientists as Troesch (2015), Feister (2015), Barry, Ohland (2009), Rudnicka (2009), Song, Choi, Rhee (2010), Byrne (2012), and others, made a significant impact on ethical standards formation among university students. Although the problems of professional ethics are studied by scientists, and the clarification of general ethical positions is mainly considered, the problem of professional engineers' ethics formation remains unnoticed.

The conceptual idea of this research is based on the postulate that the system of future professional engineer training with case study, based on the engineering activity, should be created and implemented in the educational process of higher education institutions. According to this purpose, the justification of the conditions for the organization of educational and cognitive activity of students of technical majors was made. Sets of cases from real professional practice, which stimulate active interpersonal interactions, were created.

\section{Research Methods}

A total of 418 students from two universities of Kharkiv (Ukraine) and 88 engineers from Kharkiv enterprises participated in the research. Data in this study was collected from 320 students of 6 faculties of the National Technical University Kharkiv Polytechnic Institute (NTU KhPI, Kharkiv) and 98 students of O.M. Beketov Kharkiv National University of Urban Economy. 53 graduates and 20 senior engineers from NTU KhPI, 15 leaders and experts from private enterprises "Kharkivinzhavtoservise", "New Style - Ukraine", "Insulation", "Lex", "Triada +", "New technologies", "Kyiv-Kharkivvtorresursy" were involved in the experimental activity. The choice of participants was stipulated by the variety of engineer training provided by the above-mentioned universities, and involvement 
of people in working experience was to assess the need for ethical education in engineers' practical work.

The analysis, experiment, and systematization of results were carried out through three stages. At the first stage, the study of theoretical and applied research on professional ethics teaching in technical higher education institutions all over the world was conducted. At the second stage, program and methods of experimental work were developed; the criteria and level of the components of students' professional ethics were clarified; the educational course "Professional Ethics for Engineers" was developed and implemented in the educational process. At the third stage, systematization of theoretical research and verification of experimental results were made. Implementation of research activities in business enterprises was performed.

The educational course "Professional Ethics for Engineers" combines different forms and methods of learning activity: interactive lectures, self-study, peer learning, business games, testing, questionnaires, mind mapping, brainstorming, etc. Ethical cases for engineers are divided into four groups: 1) cases which require some business (or technical) decisions; 2) cases requiring development strategy; 3) descriptive cases; and 4) problem determination cases. The educational guide, written in correspondence with this course, is divided into 12 chapters containing basic concepts of professional ethics for engineers:

- Professional ethics as part of morality. (Standards of engineers' ethical behavior and human values for civilized business world (justice, honesty, loyalty, responsibility, and tolerance are analyzed in this part);

- National mentality as an important factor in professional ethics. (The influence of the peculiarities of the national mentality on the implementation of technical activity is examined in this chapter);

- Codes of ethics and conflict resolution. (This part is based on the CRT's Principles for Business, the importance of which is to live and work together for mutually beneficial cooperation and prosperity in a healthy and fair competition);

- Negotiations as a special type of professional ethics communication. (The art of effective professional contacts is taught in this part. The interlocutor's psychological aspects, national characteristics, inner outlook, temper, and mood are taken into account in this chapter);

- Techno ethics. (The impact of technical activities on the outside world, the consequences of using technical devices are discussed in this chapter);

- Ethical leadership. (Some useful recommendations concerning effective leadership are proposed); 
- Computer ethics. (A necessity of moral nature of information technologies is emphasized. Issues related to the replacement of workers with computers, computer crimes, responsibility for computer errors, protection of confidentiality for the company, its employees and customers from cyberbullying, and many other important things are discussed in this chapter (cf. also: Stahl, Eden, Coeckelbergh, 2014));

- Ethical issues in technical products presentations. (This part informs about the norms and requirements in professional ethics presentations including the rules of fair competition);

- Ethical issues in technical products advertising. (This part highlights the idea that future engineers should realize technical production advertising according to the ethical standards);

- Moral and psychological aspects of decision-making. (The purpose of this part is to conduct an empirical analysis of both cognitive and affective components of people's reaction to moral and ethical choice dilemmas, and the influence of these components on the decision-making process and outcomes (cf. also: Song, Choi, Rhee, 2010; Byrne, 2012));

- Ethical problems of engineer-manager in Ukraine. (This part reflects information about historical aspects of Ukrainian entrepreneurs and proposes ways for inserting ethical rules to run modern engineering "honestly and without deception");

- International companies that adhere to ethical behavior. (This part describes the best examples of effective companies which follow professional ethics in their activity and analyses their norms).

Practical mastering of modern concepts in engineers' professional ethics was the main focus of our research. The theoretical material was taught in blocks for each topic, which allowed students to acquire the knowledge and effectively use it during discussions of particular cases. The case study method helped learners to form their professional orientation and holistic view of the future activity, to produce both subject-professional and social experience, to include experience in making individual and collective decisions, to develop business ethical thinking, to intensify training activity, and to build cognitive motivation.

20 groups took part in the pedagogical experiment: 10 control groups of students with training in standard curricula without providing the course of professional ethics for engineers, and 10 experimental groups with the interactive course "Professional Ethics for Engineers". According to the study plan, there were two diagnostic sections: pre-testing (before the experiment) and post-testing (after the experiment was completed). These sections included written questionnaires 
and interviews on the key topics of the course (origin and history of professional ethics, fundamental premises, ethical issues, implementation, future development). The students' level of knowledge of professional ethics, as well as their ethical qualities were evaluated with the use of the method of expert assessment, on a scale from 0 to 1 , where 1 - the highest level of the development of relevant quality or knowledge. The high professional and pedagogical competence of all the selected experts allowed for using the arithmetic mean of their estimates without additional weight coefficients.

\section{Research Results}

After pre-testing, it was clear that the experimental and control groups almost did not differ in terms of the cognitive activity, and almost two thirds of the students from these groups typically showed a low level of professional ethics concepts understanding. At the same time, according to the results of pre-testing, the students could be divided into four groups, with elementary, intermediate, upper-intermediate, and advanced levels of professional ethics skills. Among the 418 students, 41 students obtained a very positive result (9.8\%), 60 students positive result (14.35\%), 296 students - negative result (70.83\%), and 21 students showed a strongly negative result (5.02\%). The results are presented in Figure 1.

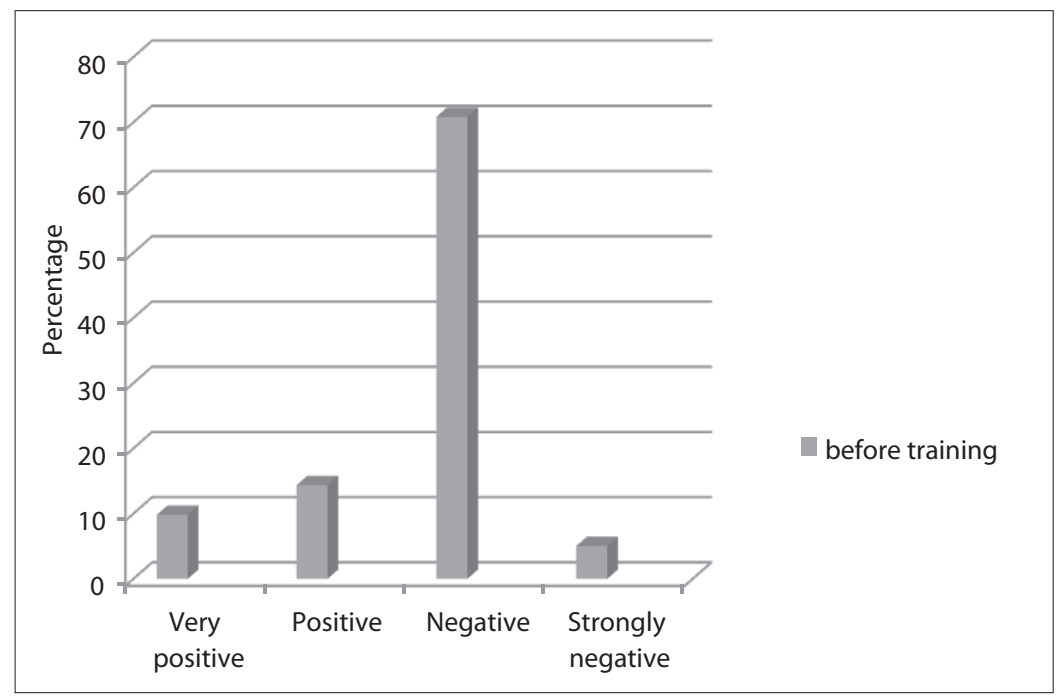

Figure 1. Level of students' professional ethics skills (first stage of experiment). 
The results of the survey demonstrate that after taking the educational course in the experimental groups, the percentage of the students who obtained a very positive result $(9.8 \%)$ and a positive result $(14.35 \%)$ of professional ethics skills formation significantly increased (from $9.8 \%$ to $24.6 \%$ ) and (from $14.35 \%$ to $33.5 \%$ ) respectively. On the contrary, the number of the students who obtained a negative result reduced from $70.83 \%$ to $41.9 \%$, and there was no student who gave a very negative response ( $0 \%$ compared to 5.02\%). The results are shown in Figure 2.

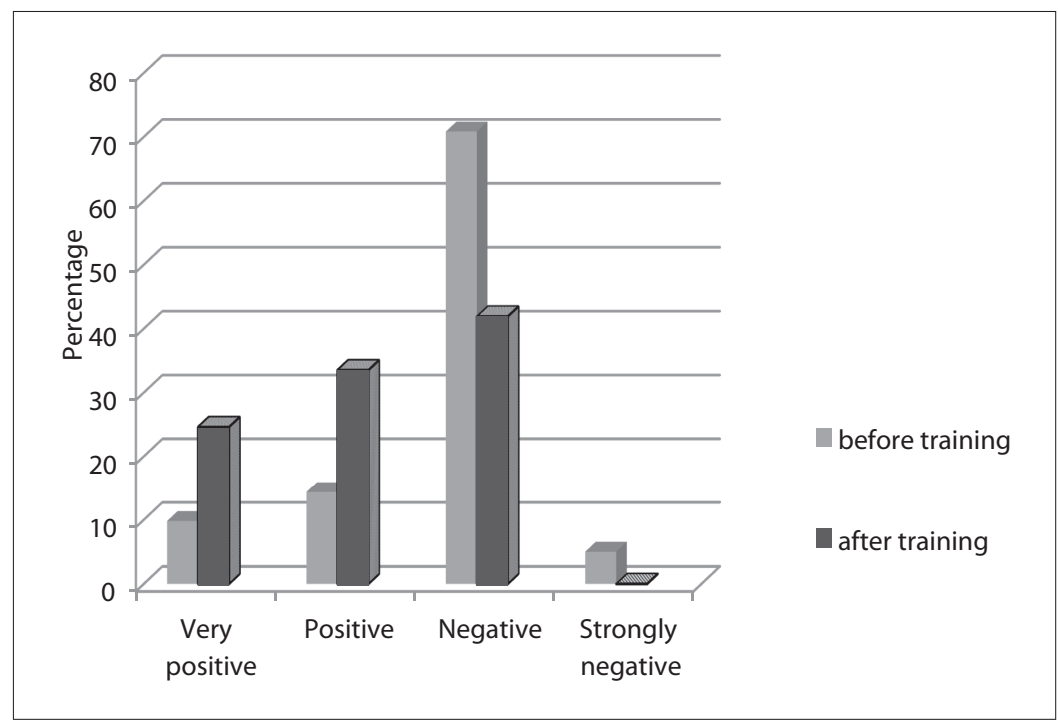

Figure 2. Dynamics of professional ethics skills formation in the experimental groups.

In the control groups, there were no major changes. The results are presented in Figure 3.

To calculate the reliability of the test tasks, the Kuder-Richardson coefficient was used, which is the most common tool for evaluating test tasks in Psych diagnostics:

$$
r_{t}=\frac{k}{k-1} \cdot \frac{\sigma_{x}^{2}-\sum p \cdot q}{\sigma_{x}^{2}}
$$

where $r_{1}$ - test reliability factor; $k$ - number of tasks in the test; $\sigma_{x}^{2}$ - variance of primary test scores; $p$ - index of difficulties; $q=1-p$ (Table 1 ).

In psychological practice, the results of an experiment are considered reliable if $r_{1}>0.6$ The obtained result $r_{1}=0.72$ confirms the reliability of the tests. 


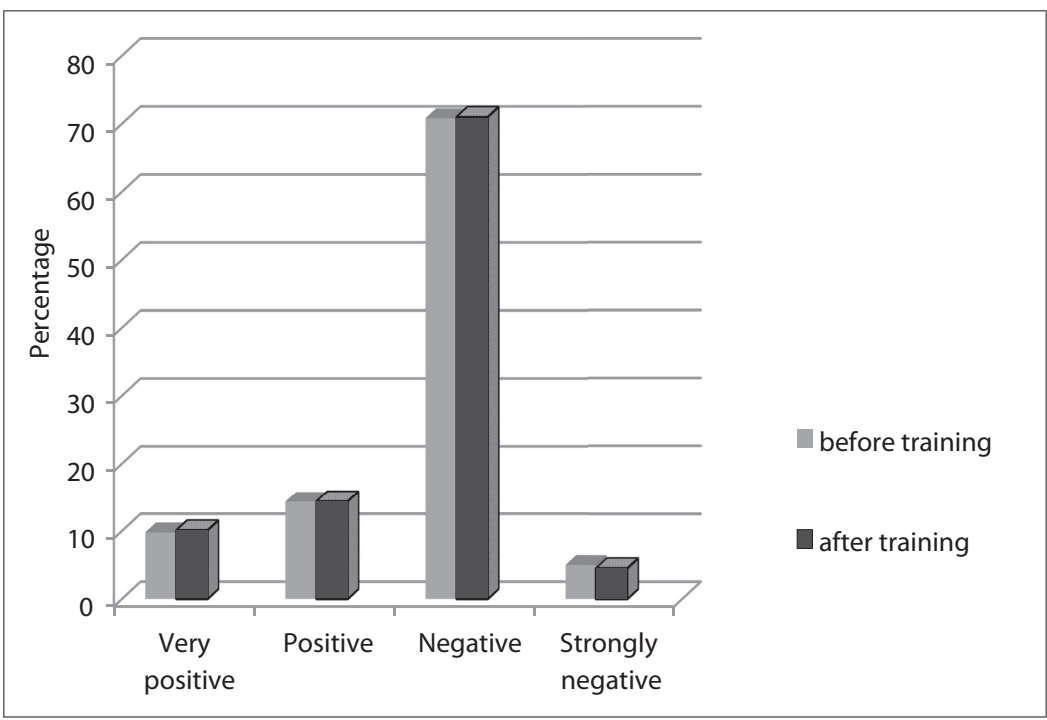

Figure 3. Dynamics of professional ethics skills formation in the control groups.

Table 1. Determination of the reliability coefficient with the use of the Kuder-Richardson method

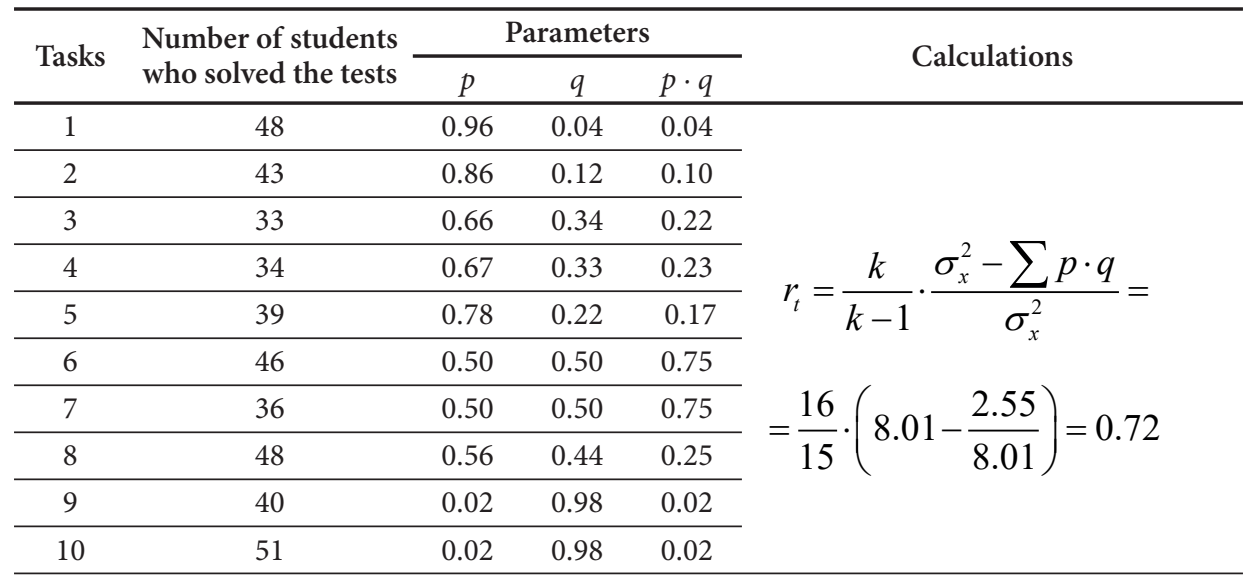




\section{Discussion}

The modern experience of engineer training shows a lack of attention to professional ethics skills of future engineers and a lack of implementation of active learning methods in the educational process. Thus, according to our interviews with the teaching staff of Kharkiv universities, only $7.8 \%$ of the teachers use professional ethics classes with the case study method systematically; thus, $82.2 \%$ of the teachers do not practice them at all. The value and efficiency of the professional ethics case study method for training future engineers are studied insufficiently.

The case study method of professional ethics is a pedagogical tool helping teachers to achieve educational goals. As part of psychological concepts, teaching with the use of the case study method helps to perpetuate the skills of responsible future ethical professional activities in the socio-economic and humanitarian spheres. The case study method makes it possible to improve the future technical specialist training under certain conditions:

- creating tasks with professional orientation, modeling them by using objective and social contexts according to future professional engineers' activity;

- creating a new role of the teacher in the training process: as a designer of cases, and as an educator who projects the ways of content presentation in particular training;

- providing peer learning based on the subject-subject relationship in the discussion of professional ethics issues.

\section{Conclusions}

The presented research is aimed at exploring professional engineer ethics training for university students, which is one of the key objectives of modern engineers' education. In the research, opinions of famous scientists, engineers, technicians, students of technical colleges were sought and analyzed. The educational course "Professional Ethics for Engineers" and the study guide "Professional Ethics for Engineers", based on the case study method, were included in the educational process (Lapuzina, 2007).

Professional engineers' ethics provides students with the important skills which help individuals to be responsible for their activity and success; these skills need and can be improved through education. Teachers play a crucial role in enabling students to gain and develop these skills. Teachers should help students to form professional engineers' ethics skills by giving responsibilities to them, cooperating 
with students to analyze professional engineers' ethics rules and standards, as well as explaining the reasons for and importance of the expected behavior.

The scientific novelty of the research is as follows:

1. The system of future engineer training was improved through the implementation of the case study technique in the professional engineers' ethics.

2. The content and structure of the concept of professional engineers' ethics in the modern global market conditions were scientifically defined.

3. The basic criteria and indicators of professional engineers' ethics were formulated.

4. Didactic, psychological, and pedagogical conditions of the case study method effective use in future engineers' professional ethics training were created.

The theoretical value of the research, as the necessity of improving the system of future engineer training in market conditions and of using this system in the educational process, was proved; the basic principles of professional ethics formation for technical specialists were defined.

The practical significance of the research is that its content and results may be used by academics to improve the educational process in the scope of professional engineers' ethics formation; the author's program and designed course "Professional Ethics for Engineers", as well as study guide "Professional Engineers' Ethics" may be used not only by professional ethics teachers, but also by students in their self-study.

The results of the experiment also showed that the cases of professional ethics promote cognitive activity of students of technical colleges and universities.

The comparative analysis of the formation of the students' skills in professional ethics, measured before and after the experiment, demonstrates the growth of dynamics in the experimental groups. Members of the experimental groups significantly improved their skills in professional engineers' ethics and acquired new knowledge of the history and development of professional ethical problems.

Static reliability of the results was determined with the use of the correlation-criteria analysis $\chi$. The results of mathematical processing of the obtained data give reason to believe that there is a direct correlation between the engineers' professional ethics cases use in teaching and the level of the students' professional ethics skills development. Our findings confirm the assumption that the proposed Professional Engineers' Ethics training significantly contributes to Engineering Pedagogy as a whole. 


\section{Acknowledgements}

The research was carried out at the National Technical University Kharkiv Polytechnic Institute, O.M. Beketov Kharkiv National University of Urban Economy, and private enterprises "Kharkivinzhavtoservise, "New Style - Ukraine, "Insulation", "Lex", "Triada +", "New technologies", "Kyiv-Kharkivvtorresursy".

\section{References}

Barry, B.E. \& Ohland, M.W. (2009). Applied Ethics in the Engineering, Health, Business, and Law Professions: A Comparison. Journal of Engineering Education, 98(4), 377-388. https://doi.org/10.1002/j.2168-9830.2009.tb01034.x

Behroozi, M., Qasemi, L. \& Fadaiyan, B. (2014). Individual and Organizational Factors Affecting on the Professional Ethics: Staff of Bushehr Custom Main Office. Procedia - Social and Behavioral Science, 143, 325-329. https://doi.org/10.1016/j. sbspro.2014.07.413

Bond, J. (2009). Professional Ethics and Corporate Social Responsibility. Process Safety and Environmental Protection, 87, 184-190. https://doi.org/ 10.1016/j.psep.2008.11.002

Byrne, E.P. (2012). Teaching Engineering Ethics with Sustainability as Context. International Journal of Sustainability in Higher Education, 13(3), 232-248. https://doi. org/10.1108/14676371211242553

DeMarco, P.M. (2017). Rachel Carson's Environmental Ethics - a Guide for Global Systems Decision Making. Journal of Cleaner Production, 140(1), 127-133. https://doi. org/10.1016/j.jclepro.2015.03.058

Farahani, M.F., \& Farahani, F.F. (2014). The Study on Professional Ethics Components among Faculty Members in the Engineering. Procedia - Social and Behavioral Sciences 116, 2085-2089. https://doi.org/10.1016/j.sbspro.2014.01.524

Feister, M.K. (2015). Exploring the Constitutive and Social Processes of Ethics in Multidisciplinary Engineering Design Teams [dissertation]. Ann Arbor, USA: Purdue University.

Gülcan, N.Y. (2015). Discussing the Importance of Teaching Ethics in Education. Procedia - Social and Behavioral Sciences 174, 2622-2625. https://doi.org/10.1016/j. sbspro.2015.01.942

Holtzhausen, D.R. (2015). The Unethical Consequences of Professional Communication Codes of Ethics: A Postmodern Analysis of Ethical Decision-making in Communication Practice. Public Relations Review 41(5), 769-776. https://doi.org/10.1016/j. pubrev.2015.06.008

Karim, N.S.A., Zamzuri, N.H.A., \& Nor, Y.M. (2009). Exploring the Relationship between Internet Ethics in University Students and the Big Five Model of Personality. Computers \& Education 53, 86-93. Retrieved January 24, 2018 from https://www.learntechlib. org/p/67222/

Kerta, S.B., Uz, C., \& Gecu, Z. (2012). Scenarios for Computer Ethics Education. Pro- 
cedia - Social and Behavioral Sciences, 46, 2706-2710. https://doi.org/10.1016/j. sbspro.2012.05.551

Krishna, A., Dangayach, G.S. \& Jain R. (2012). Business Ethics: a Sustainability Approach. Procedia - Social and Behavioral Sciences, 25, 281-286. https://doi.org/10.1016/j. sbspro.2011.10.548

Lapuzina, E.N. (2007). Delovaya etika spetsialista. Uchebnoe posobie dlya inostrannykh studentov [Business Ethics of a Specialist. A Study Guide for International Students]. Kharkiv, Ukraine: NTU KhPI. Retrieved May 4, 2018 from http://repository.kpi.kharkov. ua/handle/KhPI-Press/24112

Miloradova, N., \& Ishkov, A. (2015). Environmental Ethics as a Social, Professional and Personal Value of the Students of Civil Engineering University. Procedia Engineering, 117, 246-251. https://doi.org/10.1016/j.proeng.2015.08.158

Mounton, F., Malan, M.M., Kimppa, K.K., \& Venter, H.S. (2015). Necessity for Ethics in Social Engineering Research. Computers \& Security, 55, 114-127. https://doi. org/10.1016/j.cose.2015.09.001

Pereira, G., Brisson, A., Prada, R., Paiva, A., Bellotti, F., Kravcik, M., \& Klamma, R. (2012). Serious Games for Personal and Social Learning \& Ethics: Status and Trends. Procedia Computer Science, 15, 53-65. https://doi.org/10.1016/j.procs.2012.10.058

Rudnicka, E. (2009). Development and Evaluation of a Model to Assess Engineering Ethical Reasoning and Decision Making [dissertation]. Ann Arbor, USA: University of Pittsburgh.

Saat, M.M., Bakar, S.A., Rafai, N.H., \& Amin, A.M. (2012). Ethical Challenges in the Workplace: Are These Future Engineers Prepared? Procedia - Social and Behavioral Sciences, 40, 269-273. https://doi.org/10.1016/j.sbspro.2012.03.190

Song, S., Choi, K., \& Rhee, H. (2010). Science and Engineering Major Students' Perception of Research Ethics and Education. KEDI Journal of Educational Policy, 7(1), 175-205.

Stahl, B.C., Eden, G. \& Coeckelbergh, M. (2014). From Computer Ethics to Responsible Research and Innovation in ICT. The Transition of Reference Discourses Informing Ethics-related Research in Information Systems. Information \& Management, 51, 810-818. https://doi.org/10.1016/j.im.2014.01.001

Troesch, V. (2015). What Is It to Be an Ethical Engineer? A Phenomenological Approach to Engineering Ethics Pedagogy [dissertation]. Ann Arbor, USA: Michigan Technological University.

Verrax, F. (2017). Engineering Ethics and Post-normal Science: a French Perspective. Futures. Article in press. http://dx.doi.org/10.1016/j.futures.2017.01.009.

Wang, Q., Zhang, W., \& Zhu, Q. (2015). Directing Engineering Ethics Training Toward Practical Effectiveness. Technology in Society, 43, 65-68. https://doi.org/10.1016/j. techsoc.2015.02.004 